Article

\title{
The New Advertisers: How Foundation Funding Impacts Journalism
}

\author{
Patrick Ferrucci ${ }^{1, *}$ and Jacob L. Nelson ${ }^{2}$ \\ ${ }^{1}$ Department of Journalism, College of Media, Communication \& Information, University of Colorado Boulder, Boulder, \\ CO 80309, USA; E-Mail: patrick.ferrucci@colorado.edu \\ 2 Walter Cronkite School of Journalism and Mass Communication, Arizona State University, Phoenix, AZ 85004, USA; \\ E-Mail: jacob.nelson.1@asu.edu \\ * Corresponding author
}

Submitted: 30 May 2019 | Accepted: 8 October 2019 | Published: 17 December 2019

\begin{abstract}
Many journalism stakeholders have begun looking to philanthropic foundations to help newsrooms find economic sustainability. The rapidly expanding role of foundations as a revenue source for news publishers raises an important question: How do foundations exercise their influence over the newsrooms they fund? Using the hierarchy of influence model, this study utilizes more than 40 interviews with journalists at digitally native nonprofit news organizations and employees from foundations that fund nonprofit journalism to better understand the impact of foundation funding on journalistic practice. Drawing on previous scholarship exploring extra-media influence on the news industry, we argue that the impact of foundations on journalism parallels that of advertisers throughout the 20th century-with one important distinction: Journalism practitioners and researchers have long forbidden the influence from advertisers on editorial decisions, seeing the blurring of the two as inherently unethical. Outside funding from foundations, on the other hand, is often premised on editorial influence, complicating efforts by journalists to maintain the firewall between news revenue and production.
\end{abstract}

\section{Keywords}

advertising; foundations; journalism; news production; newsrooms; revenue

\begin{abstract}
Issue
This commentary is part of the issue "Peripheral Actors in Journalism: Agents of Change in Journalism Culture and Practice" edited by Avery E. Holton (University of Utah, USA), Valerie Belair-Gagnon (University of Minnesota-Twin Cities, USA), and Oscar Westlund (Oslo Metropolitan University, Norway / Volda University College, Norway / University of Gothenburg, Sweden).
\end{abstract}

(C) 2019 by the authors; licensee Cogitatio (Lisbon, Portugal). This article is licensed under a Creative Commons Attribution 4.0 International License (CC BY).

\section{Introduction}

Nearly three decades since newspaper circulation first began dropping, the economic outlook for journalism remains dark. The news industry's once-dependable revenue model, based on selling advertising and subscriptions, increasingly seems like an artifact from a different era (Konieczna, 2018). Despite the hopes of many news publishers, digital advertising (hereafter digital ad) revenue has not replaced print revenue losses, and while a number of news organizations have seen subscriptions climb since 2016, these tend to be the exception rather than the rule. Furthermore, the increased funding from circulation has not made up for decreases from advertising (Williams, 2019). It is against this backdrop that many journalism stakeholders have begun looking to alternative or diversified funding models for news. One model seen as a viable and exciting option is foundation-funded journalism (Benson, 2018; Scott, Bunce, \& Wright, 2019).

The rapidly expanding role of foundations in news production raises an important question: As they grow more powerful within the world of journalism, how might foundations use their influence to affect journalistic practice? Will journalists treat foundations the way they previously treated advertisers, as an important source of revenue that must be kept away from editorial 
decisions? Or will the differences in the motivations and approaches between advertisers and foundations lead to a different dynamic between foundations and the journalists they choose to fund? This study explores these issues. We draw on 40 interviews with journalists at digitally native nonprofit news organizations and employees from foundations that fund nonprofit journalism within the U.S. to better understand the influence of foundation funding on journalistic practice. We focus primarily on nonprofits because one of the biggest recipients of foundation funding over the past decade is nonprofit journalism (Ferrucci, 2019; Konieczna, 2018).

Using the lens of the hierarchy of influence model, we explore this funding as an extra-media influence on the U.S.-based nonprofit news industry (Shoemaker \& Reese, 2013; Shoemaker \& Vos, 2009). In doing so, we find that the influence of foundations on journalism parallels that of advertisers throughout the 20th centurywith one important distinction. Journalism practitioners and researchers have long opposed the influence of advertisers on editorial decisions, seeing the blurring of the two as inherently unethical (Christians, Glasser, McQuail, Nordenstreng, \& White, 2009). Yet, our interviews reveal that outside funding from foundations is often predicated on editorial influence, which complicates journalists' desire to maintain the firewall between news revenue and production. We find evidence of this influence not in the journalism that these foundation-funded newsrooms publish so much as in a variety of behind-thescenes decisions that we argue are equally significant in the news production process.

These findings build off of previous analyses of foundation-funded journalism-which have concluded that journalism publishers and funders tend to have distinct (and sometimes competing) goals (e.g., Benson, 2018; Scott et al., 2019) - by exploring the ways in which the influence of these foundations may inevitably put their desires above those of the very newsrooms they are funding. We argue that, regardless of where editorial influence comes from-advertisers, foundations, or other organizational level factors - it impacts journalists' perceived autonomy, one of the most important aspects of journalistic identity and satisfaction (McDevitt, 2003; Reich \& Hanitzsch, 2013). We conclude that collaborative efforts between journalism funders and organizations could lead to an even more skewed power dynamic than existed within the previous funding model, one where journalists cede agency to elite foundations situated outside the boundaries of journalism.

\section{Literature Review}

\subsection{Nonprofit Journalism}

Nonprofit journalism arrived in the U.S. with the opening of the Associated Press in 1846, followed by the first standalone nonprofit newsroom, the Christian Science Monitor, which began in 1908 (Groves \& Brown, 2011).
For more than a century, this model of news production comprised a small part of the news media environment (Ferrucci, 2019; Konieczna, 2018; Nee, 2013). Historically, there have not been many news nonprofits operating across the U.S. That number has skyrocketed recently: As recently as 2004, the number of nonprofit news organizations that were members of the Institute for Nonprofit News could be counted on two hands. Today, there are more than 200 (Institute for Nonprofit News, 2019). For the most part, these outlets reject legacy media's reliance on advertising. Instead, they rely on donations from individuals, foundations, and wealthy benefactors (Birnbauer, 2018).

The most established news nonprofits include the Center for Investigative Reporting, Mother Jones and ProPublica. News nonprofits are often lean operations in both staffing and focus. Some, like The Marshall Project, focus exclusively on one subject (e.g., the U.S. criminal justice system). To expand the impact of their efforts, they often partner with larger publications so their work can reach a wider audience (Konieczna, 2018). In 2018, for example, ProPublica partnered with New York magazine, Newsday and The New York Times Magazine for Pulitzer Prize-winning reporting on the Central American gang MS-13.

The growing number of news nonprofits has been accompanied by a growing number of academic studies focused on their role within and impact on the news media environment. Many of these studies focus on how audience-centric news nonprofits are compared to more traditional newsrooms (i.e., Ferrucci, 2017b; Konieczna, 2014). News nonprofits often explicitly attempt to provide citizens with agency in agenda-setting and agenda-building activities in a way that traditional for-profit news publishers have not (Konieczna, 2018). These attempts typically include "audience engagement" initiatives, such as "public newsrooms" and "listening sessions," where nonprofit journalists offer citizens opportunities to contribute to the news production process by sharing their preferences, questions, or insights (i.e., Belair-Gagnon, Nelson, \& Lewis, 2019; Ferrucci, 2015d, 2019).

One aspect of news nonprofits that remain understudied, however, is the impact of their funding model on the news they ultimately produce. In the past, scholars have examined how nonprofit status can impact content produced by a newsroom, but these studies rely solely on manifest content and do not attempt to illustrate how funding directly impacts journalistic practice (i.e., Ferrucci, 2015b, 2015c; Ferrucci, Painter, \& Kalika, 2019). Nonprofits tend to rely on diverse revenue streams to fund news operations, and recent research has begun to identify the different ways these funders impact news construction processes (Ferrucci, Russell, Choi, Duffy, \& Thorson, 2017). The revenue source that has quickly become among the most significant for news nonprofits is also one in need of more rigorous academic analysis: foundations. 


\subsection{The Rise of Foundation Funding}

As journalism organizations seek new sources of revenue to offset losses in advertising and circulation, philanthropic foundations are increasingly answering the call (Benson, 2018). Between 2009 and mid-2016, foundations gave $\$ 1.1$ billion to journalism projects within the U.S. (Konieczna, 2018). One of the biggest recipients of foundation funding over the past decade has been to nonprofit journalism (Ferrucci, 2017a). This raises an important question: How are news nonprofits that receive these funds influenced by the very foundations granting them (Benson, 2018)? In other words, how is this increasingly significant source of revenue reshaping journalistic practice?

There is reason to be wary. Journalists who once worked within traditional newsrooms perceived strict separation between advertising and editorial, which resulted in a perceived sense of autonomy over editorial content. Yet journalists within nonprofit newsrooms that receive foundation funding now find themselves in a situation where this symbolic separation between business and reporting (i.e., Coddington, 2015) no longer exists. Furthermore, because these newsrooms face a limited pool of alternative options for funding, "this power imbalance has the potential to make nonprofits susceptible to the whims of their funders," (Birnbauer, 2018, p. 177). The potential for foundations to seriously influence news nonprofits is important, especially at a moment when there is already so little public trust in journalism. In short, foundations might solve the profession's immediate financial crisis while exacerbating its long-term credibility crisis.

Conversely, the partnerships that news nonprofits pursue with other, more traditional outlets might diminish the likelihood of foundations skewing coverage in one way or another (Benson, 2018). Traditional newsrooms partner with news nonprofits because those news nonprofits demonstrate a willingness to stick to traditional norms of journalistic practice, which "shape and constrict what the nonprofits are able to do, compelling them to be aware of and even mimic mainstream news and affecting everything from their structure to their funding and, especially, their everyday operations" (Konieczna, 2018, pp. 163-164). If foundations attempt to influence news nonprofits, they do so either in tandem or competition with the traditional newsrooms with which they have partnered.

To be sure, foundations do indeed influence the newsrooms they fund. It just appears as though that influence presents itself in less obvious ways than many may have initially suspected. For instance, a recent study that drew on interviews with both foundations that fund international, nonprofit news, as well as the journalists they fund, concluded that the effect of foundation funding was not so much on journalistic autonomy, "but on the boundaries of journalism itself" (Scott et al., 2019, p. 2). The result was a situation in which the founda- tions were not dictating editorial content so much as they were shifting the ways that journalists perceived their responsibilities and the outcomes of their reporting. This sort of influence, the authors suggest, may be even more significant than were a foundation to simply push for more stories about one topic over another. By encouraging journalists to alter their own approaches to their work, foundation funding subsequently "shapes what we understand journalism to be" (Scott et al., 2019, p. 2).

Partnerships between foundations and news organizations therefore come with some ethical quandaries that researchers are just now beginning to explore (Scott et al., 2019; Wright, Scott, \& Bunce, 2018). According to a report from the American Press Institute, "the ethics of taking grants from foundations and gifts from donors to produce news is still evolving" and therefore a set of guidelines would benefit the industry (Rosenstiel, Buzenberg, Connelly, \& Loker, 2016). Furthermore, while nonprofits generally go to great lengths-on their own accord and due to legal statutes-to practice transparency in terms of where their funding comes from, this does not mean that the ways in which funding impacts a news outlet's journalism is obvious to its audience. As Konieczna (2018) pointed out, the logic behind advertising in journalism is straightforward: Advertisers pay news publishers to have their ads appear in their publications; "foundation funding, however, can be more easily obscured, and the reason for a foundation to fund a news organizations can be less clear" (p. 86).

In the past, some nonprofits have refused funding from foundations connected to a particular topic or story (i.e., Rosenstiel et al., 2016), while others feature leadership that set up newsroom firewalls to combat influence (i.e., Ferrucci, 2015a). The American Press Institute report also specifies that funders rarely review journalistic content before publication; however, this does not mean they do not significantly impact journalistic practices that result in said content. For instance, the Knight Foundation, an organization that frequently provides funding to newsrooms, typically has more than a few strings attached to its grants in the form of directives on how newsrooms should use technology or engage with audiences (Lewis, 2011). Indeed, foundations often explicitly invite newsrooms to apply for funding for stories about specific topics. Taken together, these previous studies suggest just how important it is for researchers to understand the ways in which foundations that fund journalism organizations or projects intentionally-or incidentally-influence journalistic practice (Benson, 2019).

\subsection{Foundation Funding and Engaged Journalism}

Furthermore, a foundation's influence over the newsrooms it funds need not be limited solely to editorial decisions, such as what stories the newsroom focuses on how what angle the reporters take on the topic. Some foundations instead focus on non-editorial practices within 
newsrooms, including the ways in which reporters "engage" with their audiences. The Lenfest Institute for Journalism, for example, recently began providing grants to newsrooms that agree to use audience engagement tools and services provided by the companies Hearken and GroundSource to solicit audience questions about what they would like to see the journalists cover (Bilton, 2018). Though audience engagement-which broadly refers to the notion that journalists should more explicitly communicate with and listen to the people they hope to reach-has become an appealing concept to a growing subset of the news industry, its value remains difficult to quantify (Nelson, 2018, 2019). The fact that foundations are using their funds to encourage newsrooms to pursue more engagement can therefore be seen as an attempt on their part to help newsrooms overcome the influence of quantifiable metrics, such as unique visitors, most aligned with digital advertising revenue (what Carlson, 2018, refers to as "measurable journalism") by introducing an influence of their own.

The push by foundations for newsrooms to pursue more audience engagement reveals one important way that foundations seek to influence journalistic practice outside of more obvious editorial decisions such as story selection. Others include an emphasis on certain kinds of technologies-for instance, by pushing newsrooms to embrace virtual reality products in order to secure a grant. This influence is important, both because it changes how journalists approach their work, but also because it comes with an opportunity cost. Newsrooms investing in new technologies or approaches to audience engagement are therefore not using those funds for elements of news production, such as salaries for more reporters.

As these examples show, the reason a foundation's motivation for funding journalism matters so much - and why this sort of ambiguity is so distressing-is because of the assumption that those who are providing the monetary support for news-be they advertisers, foundations, or individual donors-are somehow influencing its very production. "Dispensing funds is an exercise in power...and foundations, acting as the economic sector, hold the cards" (Birnbauer, 2018, p. 193).

This project sets out to determine how foundation funding influences news production in the U.S. To better understand how journalists reckon with these distinct influences, and how researchers can isolate and examine them, we turn now to our theoretical framework.

\subsection{Hierarchy of Influences and Social Institutions}

In his attempt to understand the impediments to a free press aimed solely at solidifying and strengthening democracy, Baker (1994) theorized that journalismunlike most services-follows a dual-product model. Within this model, news publishers need to (1) sell content to people and then (2) direct those people's attention to advertisers. In other words, journalism's eco- nomic survival has traditionally depended on its ability to serve two markets at once, unlike other kinds of consumer goods. A toaster manufacturer, for example, only needs to serve consumers (Jian \& Shin, 2015).

Because advertising revenue played such an integral role in journalism's success, Baker (1994) argued that journalists could not remove advertising's influence from the actual production of news. Of course, journalists often talk about a "wall," or boundary, between their editorial and business departments that is "so fundamental to the self-understanding of professional journalism, it's thoroughly understood as a cultural and occupational assumption" (Coddington, 2015, p. 67). However, while journalists insist that advertising does not influence practice, research suggests otherwise. Indeed, media sociologists have identified several social institutions that affect newsmaking processes, such as public relations (Feldstein, 2010), large corporations (Hackett \& Uzelman, 2003), educational systems (McDevitt \& Sindorf, 2012) and large technology firms (Ferrucci, 2018; Russell, 2019). Advertising is therefore just one of a number of institutions that impacts journalistic practice in a variety of ways (Carlson \& Lewis, 2015; Schauster, Ferrucci, \& Neill, 2016; Shoemaker \& Vos, 2009).

The hierarchy of influences model examines how forces such as advertising restrict or enable the movement of information through media (Schudson, 2012; Shoemaker \& Reese, 2013). Fundamentally, the theory "takes into account the multiple forces that simultaneously impinge on media and suggest how influence on one level may interact with that at another" (Shoemaker \& Reese, 2013, p. 1). A nuanced understanding of influences on news production illustrates that many factors impact choices made during news production (Vos \& Russell, 2019). The key contribution of the hierarchy of influences is the identification of five levels of analysis.

Within the Shoemaker and Reese (2013) conceptualization, these five distinct levels all work together to influence news. The individual level reveals how specific characteristics of journalists affect news choices. The communication routines level looks at the practices and norms that are prevailing across the journalism industry. The organizational level involves characteristics of specific news organizations such as leadership that impact newswork. The social institution level investigates how peripheral and tangential institutions such as public relations, the audience, advertisers, or government influence the news. And, finally, the social system level examines how "the news media reflects the organizing philosophy of a society" (Shoemaker \& Vos, 2009, p. 98).

As the boundaries between journalism and other institutions blur, more peripheral ones have begun directly influencing journalistic work (Belair-Gagnon \& Holton, 2018; Carlson \& Lewis, 2015). For instance, the rise of sophisticated audience measurement tools has resulted in a news media landscape where journalists now routinely check to see how many people clicked on their 
stories, illustrating the power some technology companies exert on practice (Nelson \& Webster, 2016). Baker (1994) focused primarily on advertising because, as recently as a decade and a half ago, the vast majority of journalism market models relied solely on advertising as a revenue stream. That is no longer the case (Ferrucci \& Nelson, 2019).

The advent of nonprofit journalism has made it increasingly important for researchers to study the people and forces behind the varied revenue sources that this model entails. Doing so will help researchers understand these boundaries and examine institutions that "enter into a collaborative symbiotic relationship" with journalism (Shoemaker \& Reese, 2013, p. 95). With new market models diversifying revenue streams and eliminating many old journalistic norms (Ferrucci, 2015d; Konieczna, 2014), the social institutional level of influence on news practice is an increasingly important area of inquiry as it significantly affects journalistic autonomy (Lowrey, Sherrill, \& Broussard, 2019; Vos \& Russell, 2019).

In short, this study seeks to build off of this previous work that has explored the increasingly important role of foundations in journalism by exploring how this new source of revenue wields its influence within the newsrooms that depend on their funding. Our driving research questions are: How do foundations' influence on the newsrooms they fund differ from advertisersthe previously more common revenue source for journalism? Has journalism simply swapped out one revenue source, and consequently one form of journalistic influence, for another? Or are foundations serving a different role altogether?

\section{Method}

\subsection{In-Depth Interview and Data Analysis}

In-depth interviews remain an essential methodological approach for researchers interested in uncovering complicated processes, patterns and behaviors (McCracken, 1988; Miles \& Huberman, 1994). The method can prove particularly effective for understanding and uncovering the motivations of participants (Wimmer \& Dominick, 2006). In this study, the first author conducted in-depth phone interviews with 37 full-time journalists at $\mathbf{3 0}$ different news nonprofits in the U.S. to understand how they perceive the relationship between their organizations and foundations. These data were collected as part of a much-larger study between 2015-2018.

Interviews ranged from 46 to 105 minutes with an average time of roughly 71 minutes. The participants' experience in journalism ranged from 7 months to 37 years. The interview protocol consisted of broad, open-ended questions meant to encourage detailed answers to the questions (McCracken, 1988). All participants were asked the same set of questions, but follow-up questions varied depending on the interviewee. This follows the protocol adhered to by McCracken (1988). The researcher promised all participants anonymity and confidentiality. Following these interviews, in 2018, the first author conducted in-depth interviews with seven employees from five different funding foundations, decision-makers from journalism donors such as The Knight Foundation or the Democracy Fund. These interviews lasted, on average, 34 minutes. Interviews ended when the first researcher believed a saturation point was reached, something that scholars believe is the time for data collection to conclude since it means no new insight is being produced (Emerson, Fretz, \& Shaw, 2011).

For data analysis purposes, the first author utilized the process described by Emerson et al. (2011), which features a three-step procedure. First, the researcher simply read through the whole of the data and made notes, a stage called writing memos. Second, the researcher returned to the data, conducting a close read while identifying themes and patterns, a stage called open coding. Finally, the researcher read through the data one more time, this time reading it with themes in mind and beginning a rough draft of the findings, a stage called focused coding. After writing this draft of the findings, the two researchers met to discuss changes to the findings and the second author then completed a rough draft of the discussion based on the findings.

It is important to note that these data stem entirely from organizations based within the U.S. Though the result is a dataset admittedly limited in terms of its global scope, it is also one that centers on a nation where much of the discourse surrounding foundation-funded journalism continues to unfold. So, while our findings are not representative of global trends, they remain an important illustration of the dynamic between foundations and news publishers within a country in which these collaborations are occurring more frequently than ever before.

\subsection{An Emphasis on Perception}

This study analyzes journalists' perceptions of influence. It does not purport to reveal anything other than how the journalists interviewed see the world around them. Our findings do not reveal how journalists represent the field at large or how they are discursively constructing definitions or boundaries of said field. Rather, this study simply illustrates how participants perceive the impact of foundation funding. Consequently, it is impossible to definitively state know how much or how little what journalists perceive about foundation influence aligns with reality. However, because the individuals interviewed worked in journalism before and after foundation funding, we believe that they are in a good position to understand how their jobs have changed, and to reflect on the influences responsible for those changes. Furthermore, the majority of the media sociology research canon that examines influence relies on perception, and we believe that this study follows in the same tradition.

Finally, it is important to note that while this study utilizes a relatively large sample for a study of this kind, 
these results are, consistent with the majority of interview studies, not generalizable.

\section{Findings}

This study seeks to understand how journalists at digitally native news nonprofits and employees of foundations that often fund these nonprofits perceive the influence of foundation finances impact journalistic practice. After analyzing the data, it became clear that foundation funding often went to news nonprofits pursuing three types of initiatives: specific, technology-driven projects; audience engagement projects; and projects intended to push journalists to expand their daily work beyond traditional routines.

\subsection{Tech-Driven Projects}

The most common theme to emerge from the data concerned foundation funding that came with an expectation of journalists using specific new technologies. All but one journalist interviewed mentioned this type of funding, and all the participants from foundations did as well. Essentially, participants noted that foundations often distribute funds or grants to organizations willing to implement new practices surrounding new technologies. "For a while," said one journalist, "it was all about [virtual reality]. Some biggies like The Guardian made some cool stories using VR and now these places would give anyone money if they promised to use it" (throughout Section 4, all quotes are personal communications). The problem, according to journalists, is that these new technologies are only new for a short amount of time or, often enough, their audiences do not seem willing to adopt these technologies themselves. This leads some journalists to feel they must continuously chase the latest tech trends to receive foundation funding. As one journalist said:

All [foundations] care about is how cool something sounds right then. Let's be honest, most of these [foundations] are run by journalists who are [around my age of 60]. They read a proposal with something cool sounding on it, and they're all over it. They spread their money around to anything they think is innovative. They're helping a lot of different startups, and that's a good thing, but a lot of that money goes to waste when these startups fail. Those funds could have gone to help support newsrooms they already funded. If I wanted to make sure I kept [foundation funding], I would have to reinvent this place every year or so.

Implicit in this quote is another important finding that consistently came up: Journalists believe they receive funding to utilize a trending technology; unfortunately, this means that when the grant funds run out, these journalists are unlikely to receive more, because the foun- dation identified the next new other technology, and has thus moved onto the next newsroom attempting to adopt it.

This situation leaves a newsroom with a staff trained in something the organization cannot afford to apply anymore. Even worse, this might be a technology that does not even seem to connect with the public, either. One participant from a foundation agreed with this notion, but also pointed out that newsrooms accept funds understanding that these funds will eventually end. They are not intended to be a constant revenue source. Instead, they are intended to fund newsroom experimentationto give newsrooms the means by which they can see if a new technological tool will resonate with readers, thus ideally putting them on the path to self-sustainability:

It sucks. I said it. It sucks when one of the newsrooms we've worked hard to support cannot make it. We provide this infrastructure and guidance, but sometimes it doesn't work and that makes you feel bad. There are people involved. The thing is, we're upfront with our newsrooms. We're not here to support you till the Earth ends. Our job is help find journalism's future. That means seeking out innovation, finding the model that will unlock journalism's potential to work with the public and, yes, finding the model that can become self-sustainable. You know, we may never find that. I don't believe it; I think we will. But our mission isn't to keep newsrooms alive. It's to look toward the future.

The problem with this logic is that journalists believe that these specific technologies typically do not make their stories better. In fact, the participants suggested that the implementation of these technologies are typically done just for public relations purposes. "We get to say, 'Oh, hey, we do this,"' said one journalist. She added, "Who cares that we do this thing? Does it actually make our work better? No. It's basically public relations for the newsroom." Speaking about an audience engagement platform that has grown popular in newsrooms, one person from a foundation that helps nonprofits pay for it, said, "Hell, I have no idea if it works. We hope so." A journalist, referring to the same platform, explained:

I believe in the mission or the reason behind [the platform]. It's the right thing to do. In this case, to me, it was totally unnecessary though. I felt like [my editors] needed to justify having [the platform], which meant using it more than we needed to. When [one editor] suggested it before I started, I didn't realize I was being forced to use it, not asked. That kind of stuff happened often. I remember the whole thing so well because it opened my eyes, you know? I came to understand that if someone was paying us to do something, we did it no matter what. I've written some great stories that way since, though. We still have it, but I don't think it's a priority since the [funded period] stopped. 
In short, both journalists and funders agreed that foundations exercise influence on news production practices. Foundations often fund the adoption of new technologies within newsrooms, which they hope will open the door to journalism's eventual sustainability. Journalists follow suit and proceed to utilize these new technologies, sometimes with no small amount of reluctance.

\subsection{Engagement}

A majority of the journalists interviewed, and all of the foundation employees, said that foundations currently prioritize audience engagement within newsrooms. As one foundation employee said, "It's it right now. We're about focusing our attentions and resources on galvanizing engagement between journalists and the public. That's where it is at for us." Journalists agreed. One noted that, "No matter the story, someone is going to ask me how I worked with the community" (emphasis by speaker, italics added by authors). He went on, adding, "It really matters not at all whether engagement or whatever we should call it makes sense for the particular story." Journalists consistently described how they felt foundations influenced the incorporation of routines that at least motioned toward giving the audience agenda-setting power. One journalist said:

Ever since we took [a foundation's] money, we became an 'audience first' newsroom. Weren't we always that? Isn't journalism all for the public? Somehow, according to my editor and [the foundation], asking [random people] what they care about is the new journalism.

One journalist disparaged the notion that the public should have agenda-setting power, despite the fact that his newsroom has begun prioritizing this very goal after receiving a foundation grant intended to pay for the adoption of an engagement platform. He said:

The people are not as knowing about a story as I am. They haven't researched the topic. They haven't talked to a lot of people outside of social circles. I read legal briefs or other places' journalism. I don't think people do that. It can become infuriating when my bosses or Columbia Journalism Review or Jeff Jarvis tells me I'm missing an opportunity by not letting people tell me what to do. I get the idea, you know, but most people are ignorant or can't be expected to know as much as I do. It's not their job to look into something. They aren't journalists.

Although audience engagement advocates believe that giving the public more power in news production will increase their trust in and loyalty to news, many of this study's participants argued that the opposite is true. "It's basically telling people we don't know what we're doing," one journalist said. Even one foundation employee who funds various engagement efforts noted that, at first, he wondered if the rhetoric surrounding many of today's engagement companies or public intellectuals hurt journalism. "If you read between the lines," the foundation employee said, "all you hear is that journalists aren't professional enough to understand their roles." Another journalist summed it up thusly:

I've been in this business a long time. What people in academia, no offense, or not actually doing journalism say now about what they currently call engagement isn't very different than others said 30 years ago. Jay Rosen, for example, is still Jay Rosen. And back then, some places jumped on the bandwagon but most stayed off. The difference is now we have these [foundations] waving money at us, money we need, if we just do this thing or that thing that will engage our public. When money is offered, we listen. Don't think for a second, OK, that taking that money and doing this stuff isn't changing journalism.

Over and over again, journalists discussed how foundation funding for engagement influenced how they go about finding and reporting on stories. Those who, at least partially, disagreed with the notion that audience engagement is worthwhile, saw this shift as something of an opportunity cost. "I think people need to know the news. But I can only write so much in a day," one journalist said, "when I have to do all this [engagement] stuff, it takes time and really harms the news product, I think."

\subsection{Expanding the Journalists' Role}

The final theme that emerged from the data focused on the extra responsibilities that journalists sometime inherit when their organization accepts foundation funds. "The grant we have makes me do certain things when it comes to sources, but I also am forced to write up the 'results' of my work," one journalist said. "Not only do I not understand, but that takes time," in other words, a foundation grant to this journalist's newsroom came with a directive for this journalist to explicitly describe to the public how the organization spent the grant funds. This sharing could come in the form of articles in trade magazines such as Columbia Journalism Review, testimonials for the foundation's website or, more commonly, presentations at industry conferences and events. "To stay relevant and important," said one foundation employee, "we need to have our name out there and boast about what we're funding." In short, journalists who accepted foundation funding often found that the foundation expected publicfacing missives about what the funds were for, how they ultimately were used, and to what effect.

Again, journalists perceived these added as opportunity costs. "I'm a journalist," one said, "this type of stuff basically makes me [the foundation's] PR man. First, I'm not good at it and, second, I could be doing the work [the foundation] is funding me to do." The idea that this 
work was essentially public relations for the funder came up often. The result was a bit of skepticism on the part of the journalists, who suggested that these foundations funded journalism not solely to improve democracy or the mission, but rather to amass more power in the industry. One journalist said:

Look, I get it. They're giving [my organization] money. There needs to be oversight and we should be very deliberate and transparent when keeping track of what we do with grants. That's obvious and necessary. And I understand them keeping track of this. But [this foundation], they're all about promoting themselves. We have to, especially my editor, travel across the country and talk to these muckety mucks in journalism, many who don't do journalism, and make it sound like we're doing more than we are here. It's all to make [the foundation] seem cutting edge or whatever.

Unsurprisingly, the foundation employees did not see these efforts quite so uncharitably. Instead, they saw these efforts as another necessary part of their mission to help solve journalism's most pressing problems. As one foundation employee said, "Everyone wants to find the thing that saves journalism. We want others to know how we're running it."

\section{Discussion}

These findings corroborate prior studies that have described how foundation funding within journalism broke down "boundaries of professionalism to invite external critique, contribution, and collaboration" (Lewis, 2012, p. 330). It also builds off a growing body of literature that has explored how-and to what extent-foundations influence the very journalism that they fund (Scott et al., 2019; Wright et al., 2018). The primary contribution of our study is to evaluate the ways in which these foundations' influence on journalistic practice mirrors or differs from that of the advertisers that were once (and, for many newsrooms, continue to be) the primary source of revenue. At a practical level, our findings reveal how, potentially, the influence of foundation funding within journalism actually unfolds. In doing so, they shed light on the two structural obstacles often overlooked in discussions about it: First, that journalism funders have different goals from the newsrooms they are funding; and second, that newsroom managers who apply for and accept foundation grants may feel more passionate about the directives associated with those grants than the journalists ultimately tasked with following them.

Our findings also show how foundations, like advertisers, could indeed have an influential role on how journalists approach their work. Yet, unlike advertisers, foundations do not face a "firewall" that separates their goals from those of the journalists they are funding. In a perfect world, this firewall would be unnecessary, because the goals of the foundations and the journalists would be one and the same-to improve the quality of the news (Ferrucci, 2019). But as these findings illustrate, the ideas that foundations have for how to improve news quality (e.g., more audience engagement, more technologically driven projects) are not necessarily the same ideas as those actually working within the newsrooms. In the previous, advertising-driven era, no journalist at a reputable organization would be asked to write a story to appease a specific advertiser. In the world of foundationfunded journalism, however, journalists are asked to embrace certain tools and approaches to their work because doing will help that newsroom secure or maintain their foundation funding. This finding is consistent with previous work by Scott et al. (2019), which concluded that foundations do not necessarily influence editorial decisions so much as they alter journalistic roles and practices, primarily by putting on premium on what they referred to as "non-editorial activities" (p. 10).

\subsection{The Trouble with Competing Goals}

Furthermore, because foundations within the U.S. tend to focus more on solving problems facing the news industry as a whole rather than on those facing individual news organizations, they want to both fund journalistic experimentation with uncertain outcomes, and to share those outcomes with the broader news media environment. The result is a situation where news nonprofits and foundations increasingly work together, yet are motivated by distinct, sometimes conflicting goals. The former often want to survive from one year to the next, while the latter often want to figure out what journalistic techniques can help all news organizations reach sustainability. From the point of view of those funding journalism, one news organization failing is an acceptable step in the search for insights about what will work and what will not. For news nonprofits, on the other hand, failure is the end of the line.

This means that journalists sometimes find themselves not only implementing a new digital tool or participatory reporting approach they don't believe in, but then also writing about the results of their efforts for audiences they don't care to interact with in that manner. Compounding this issue is the fact that foundation employees also described an ongoing concern that grant recipients were generally less likely to report failures than successes out of fear that disclosing a failed experiment will diminish the likelihood of continued funding. This makes the increasing role of foundations in journalism even more fraught: If they seek to improve journalism via their own interventions, they may be less than willing to be transparent about when those interventions do not succeed. Taken together, these findings suggest that collaborative efforts between journalism funders and publishers to transform the profession face challenges posed by a potential skewed power dynamic between those in dire need of help and those who hope to provide it. 


\subsection{The Firewall Has Yet to Materialize}

Shoemaker and Reese (2013) argued that influence from social institutions affect journalism practice, but professional journalists often work to assuage, eliminate or, at least, control this influence. However, none of those aforementioned social institutions, besides advertising, historically funded journalism, so professionals felt autonomous over those influences (Lowrey et al., 2019). Because advertising served as the main revenue stream for the news industry, journalists felt it imperative to invent a figurative-and sometimes literal- "wall" separating the business and editorial side of an organization (Baker, 1994). As this study's findings illustrate, in some cases, U.S.-based foundations are increasingly funding the country's growing number of news nonprofits, but that firewall has yet to materialize.

Perhaps the growing role of foundation funding will lead to newsrooms and foundations to more openly discuss the establishment of this sort firewall, or some variation that might prove more fitting for this revenue model. Indeed, in the past a firewall between advertising and editorial was an industry-wide normative standard, something that existed ubiquitously across the industry. With foundations, however, each organization seems to have its own philosophy surrounding foundation funds, which means that industry-spanning normative beliefs, including ones concerning ethics, could be devolving into organization-specific beliefs as happens when normative practices become different depending on media organization (Ferrucci \& Taylor, 2019).

The absence of that firewall gets at a larger and more unique finding, which is that foundations are in some cases playing the role once held by advertisers, yet are doing so in an environment where the lines between the two are still being drawn. To be sure, although the firewall between advertising and the editorial function of a newsroom remains, for the most part, clear and strong (Coddington, 2015; Schauster et al., 2016), advertisers still influence news in many ways (Baker, 1994). However, in a dramatic departure from this dynamic, foundations often aspire to influence the newsrooms they fund, by, say, disrupting certain editorial and organizational practices. In other words, while these foundations provide essential support for journalism, they also impact the very work that they are funding.

For example, our findings suggest that journalism funding-foundations can seek to provide support for engagement work specifically, which stems from their belief that traditional journalism has done a poor job working with and listening to their audiences, to the detriment of the news and its standing among the public (Nelson, 2019). As our findings show, news organizations sometimes pursue foundation funding even when the employees within those organizations don't agree with those foundation's beliefs about journalistic practice. In other words, journalists working in newsrooms that are recipients of foundation funding may find themselves folding engaged journalism techniques into their news routines-whether they want to or not. The result is a situation where these foundations have arguably more control over news production processes than advertising ever did.

\subsection{Limitations}

This study faced a few important limitations. First, our data stem from U.S.-based foundations and news organizations. Obviously, however, the news media landscape within the U.S. is not the same as it is in other nations across the globe. The economic problems that news publishers face in one country-and the paths they may choose to overcome those challenges-differ from one country to the next. Indeed, as a report focused on media startups in the Global South recently noted, foundationsupport is less in vogue than the pursuit of audiencesupported revenue via individual donations and memberships (Schiffrin, 2019). While the question of journalistic sustainability is one that newsrooms across the globe continue to face, and one that philanthropic organizations increasingly seek to answer, we do not mean to suggest that what happens in the U.S. is universal. Furthermore, as with most studies of this methodological nature, these findings only represent the data collected for this study, which features the perceptions of the participants. This study is therefore not generalizable and not representative of the journalism field as a whole.

To summarize, journalists increasingly accept funding from foundations, and with that funding comes a significant amount of influence on journalistic practice. Journalists accept this influence (albeit sometimes begrudgingly) in a way that suggests the firewall that formerly existed between editorial and revenue in the era of advertising has yet to reappear in this emerging era of foundation funding. Furthermore, while both of these groups-journalists and foundations-ultimately aspire to the same goal of strengthening democracy through a strong fourth-estate, their sometimes divergent goals can result in a lack of accomplishment, disappointed local journalists, or both.

While this study focuses on foundation support, future research should examine other social institutions increasingly overlapping and encroaching on journalism boundaries. As market models continue to evolve and revenue streams continue to diversify, more and more outside institutions are bypassing traditional boundaries. These influences need to be further interrogated so that their implications for journalism can be fully understood.

\section{Acknowledgments}

Publication of this article was funded by the University of Colorado Boulder Libraries Open Access Fund. The authors would also like to acknowledge this article's reviewers who helped immensely in the conceptualization and framing of this piece. 


\section{Conflict of Interests}

The authors declare no conflict of interests.

\section{References}

Baker, C. E. (1994). Advertising and a democratic press. Princeton, NJ: Princeton University Press.

Belair-Gagnon, V., \& Holton, A. E. (2018). Strangers to the game? Interlopers, intralopers, and shifting news production. Media and Communication, 6(4), 70-78.

Belair-Gagnon, V., Nelson, J. L., \& Lewis, S. C. (2019). Audience engagement, reciprocity, and the pursuit of community connectedness in public media journalism. Journalism Practice, 13(5), 558-575.

Benson, R. (2018). Can foundations solve the journalism crisis? Journalism, 19(8), 1059-1077.

Benson, R. (2019). Paywalls and public knowledge: How can journalism provide quality news for everyone? Journalism, 20(1), 146-149.

Bilton, R. (2018). A new $\$ 650 \mathrm{~K}$ grant will help pay for newsrooms to adopt tools like Hearken and GroundSource. NiemanLab. Retrieved from https:// www.niemanlab.org/2018/01/a-new-650k-grantwill-help-pay-for-newsrooms-to-adopt-tools-likehearken-and-groundsource

Birnbauer, B. (2018). The rise of nonprofit investigative journalism in the United States. New York, NY: Routledge.

Carlson, M. (2018). Confronting measurable journalism. Digital Journalism, 6(4), 406-417. https://doi.org/ 10.1080/21670811.2018.1445003

Carlson, M., \& Lewis, S. C. (2015). Boundaries of journalism: Professionalism, practices and participation. New York, NY: Routledge.

Christians, C. G., Glasser, T. L., McQuail, D., Nordenstreng, K., \& White, R. A. (2009). Normative theories of the media: Journalism in democratic societies. Urbana, IL: University of Illinois Press.

Coddington, M. (2015). The wall becomes a curtain: Revisiting journalism's news-business boundary. In M. Carlson \& S. C. Lewis (Eds.), Boundaries of journalism: Professionalism, practices, and participation (pp. 67-82). New York, NY: Routledge.

Emerson, R., Fretz, R., \& Shaw, L. (2011). Writing ethnographic fieldnotes. Chicago, IL: University of Chicago Press.

Feldstein, M. (2010). Poisoning the press: Richard Nixon, Jack Anderson, and the rise of Washington's scandal culture. New York, NY: Farrar, Straus, and Giroux.

Ferrucci, P. (2015a). Follow the leader: How leadership can affect the future of community journalism. Community Journalism, 4(2), 19-35.

Ferrucci, P. (2015b). Murder incorporated: Market orientation and coverage of the Annie Le investigation. Electronic News, 9(2), 108-121.

Ferrucci, P. (2015c). Primary differences: How market orientation can influence content. Journal of Media
Practice, 16(3), 195-210.

Ferrucci, P. (2015d). Public journalism no more: The digitally native news nonprofit and public service journalism. Journalism, 16(7), 904-919.

Ferrucci, P. (2017a). Exploring public service journalism: Digitally native news nonprofits and engagement. Journalism \& Mass Communication Quarterly, 94(1), 355-370.

Ferrucci, P. (2017b). Technology allows audience role in news construction. Newspaper Research Journal, 38(1), 79-89.

Ferrucci, P. (2018). It is in the numbers: How market orientation impacts journalists' use of news metrics. Journalism. Advance online publication. http://doi. org/10.1177/1464884918807056

Ferrucci, P. (2019). Making nonprofit journalism: Market models, influence and journalism practice. New York, NY: Routledge.

Ferrucci, P., \& Nelson, J. L. (2019). Lessons from the megachurch: Understanding journalism's turn to membership. Journal of Media and Religion, 18(2), 61-73.

Ferrucci, P., Painter, C. E., \& Kalika, A. (2019). How market orientation and ethics affected coverage of marijuana legalization. Newspaper Research Journal, 40(3), 391-404.

Ferrucci, P., Russell, F. M., Choi, H., Duffy, M., \& Thorson, E. (2017). Times are a changin': How a merger affects the construction of news processes. Journalism Studies, 18(3), 247-264.

Ferrucci, P., \& Taylor, R. (2019). Blurred boundaries: Toning ethics in news routines. Journalism Studies, 20(15), 2167-2181. http://doi.org/10.1080/ 1461670X.2019.1577165

Groves, J., \& Brown, C. (2011). Stopping the presses: A longitudinal case study of the Christian Science Monitor transition from print daily to web always. International Symposium on Online Journalism, 1(2), 86-128.

Hackett, R. A., \& Uzelman, S. (2003). Tracing corporate influences on press content: A summary of recent NewsWatch Canada research. Journalism Studies, 4(3), 331-346.

Institute for Nonprofit News. (2019). Member Directory. Institute for Nonprofit News. Retrieved from https:// inn.org/members

Jian, L., \& Shin, J. (2015). Motivations behind donors' contributions to crowdfunded journalism. Mass Communication and Society, 18(2), 165-185.

Konieczna, M. (2014). Do old norms have a place in new media? A case study of the nonprofit MinnPost. Journalism Practice, 8(1), 49-64.

Konieczna, M. (2018). Journalism without profit: Making news when the market fails. New York, NY: Oxford University Press.

Lewis, S. C. (2011). Journalism innovation and participation: An analysis of the Knight News Challenge. International Journal of Communication, 5, 1623-1648. 
Lewis, S. C. (2012). From journalism to information: The transformation of the Knight Foundation and news innovation. Mass Communication and Society, 15(3), 309-334.

Lowrey, W., Sherrill, L., \& Broussard, R. (2019). Field and ecology approaches to journalism innovation: The role of ancillary organizations. Journalism Studies, 20(15), 2131-2149. https://doi.org/10.1080/ 1461670X.2019.1568904

McCracken, G. D. (1988). The long interview. Newbury Park, CA: Sage Publications.

McDevitt, M. (2003). In defense of autonomy: A critique of the public journalism critique. Journal of Communication, 53(1), 155-164.

McDevitt, M., \& Sindorf, S. (2012). How to kill a journalism school: The digital sublime in the discourse of discontinuance. Journalism \& Mass Communication Educator, 67(2), 109-118.

Miles, M. B., \& Huberman, A. M. (1994). Qualitative data analysis. Thousand Oaks, CA: Sage.

Nee, R. C. (2013). Creative destruction: An exploratory study of how digitally native news nonprofits are innovating online journalism practices. International Journal on Media Management, 15(1), 3-22.

Nelson, J. L. (2018). The elusive engagement metric. Digital Journalism, 6(4), 528-544.

Nelson, J. L. (2019). The next media regime: The pursuit of 'audience engagement' in journalism. Journalism. Advance online publication. https://doi.org/ $10.1177 / 1464884919862375$

Nelson, J. L., \& Webster, J. G. (2016). Audience currencies in the age of big data. International Journal on Media Management, 18(1), 9-24.

Reich, Z., \& Hanitzsch, T. (2013). Determinants of journalists' professional autonomy: Individual and national level factors matter more than organizational ones. Mass Communication and Society, 16(1), 133-156.

Rosenstiel, T., Buzenberg, W., Connelly, M., \& Loker, K. (2016). Charting new ground: The ethical terrain of nonprofit journalism. American Press Institute. Retrieved from https://www.americanpressinstitute. org/publications/reports/nonprofit-news

Russell, F. M. (2019). Twitter and news gatekeeping: Interactivity, reciprocity, and promotion in news organizations' tweets. Digital Journalism, 7(1), 80-99. http://doi.org/10.1080/21670811.2017.1399805

Schauster, E. E., Ferrucci, P., \& Neill, M. S. (2016). Native advertising is the new journalism: How deception affects social responsibility. American Behavioral Scientist, 60(12), 1408-1424.

Schiffrin, A. (2019). Fighting for survival: Media startups in the Global South. Center for International Media Assistance. Retrieved from https://www.cima. ned.org/blog/fighting-for-survival-new-report-onmedia-startups-in-the-global-south

Schudson, M. (2012). The sociology of news. New York, NY: W.W. Norton.

Scott, M., Bunce, M., \& Wright, K. (2019). Foundation funding and the boundaries of journalism. Journalism Studies, 20(14), 2034-2052. http://doi.org/ 10.1080/1461670X.2018.1556321

Shoemaker, P. J., \& Reese, S. D. (2013). Mediating the message in the 21st century: A media sociology perspective (3rd ed.). New York, NY: Routledge.

Shoemaker, P. J., \& Vos, T. P. (2009). Gatekeeping theory. New York, NY: Routledge.

Vos, T. P., \& Russell, F. M. (2019). Theorizing journalism's institutional relationships: An elaboration of gatekeeping theory. Journalism Studies. Advance online publication. http://doi.org/10.1080/1461670X.2019. 1593882

Williams, R. (2019). Digital ad sales, subscriptions can't save most newspapers. MediaPost. Retrieved from https://www.mediapost.com/publications/article/ 335469/digital-ad-sales-subscriptions-cant-savemost-ne.html

Wimmer, R. D., \& Dominick, J. R. (2006). Mass media research: An introduction (8th ed.). Belmont, CA: Thomson, Wadsworth.

Wright, K., Scott, M., \& Bunce, M. (2018). Foundationfunded journalism, philanthrocapitalism and tainted donors. Journalism Studies, 20(5), 675-695.

\section{About the Authors}

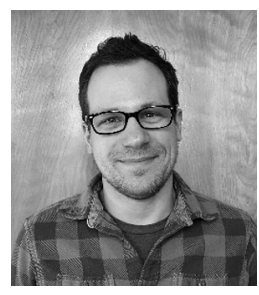

Patrick Ferrucci (PhD, University of Missouri) is an Assistant Professor in the Department of Journalism in the College of Media, Communication and Information at University of Colorado Boulder. His research primarily concerns itself with how shifting notions of 'organization' in journalism lead to influence on journalism practice. Specifically, his work examines organization-level variables' impact on message construction.

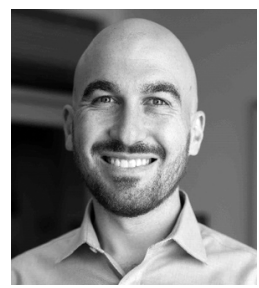

Jacob L. Nelson (PhD, Northwestern University) is an Assistant Professor at the Walter Cronkite School of Journalism and Mass Communication at Arizona State University, and a Fellow with Columbia University's Tow Center for Digital Journalism. He uses qualitative and quantitative methods to study the changing relationship between journalism and the public. 